\title{
Vooronderstellings wat die eskatologie beïnvloed
}

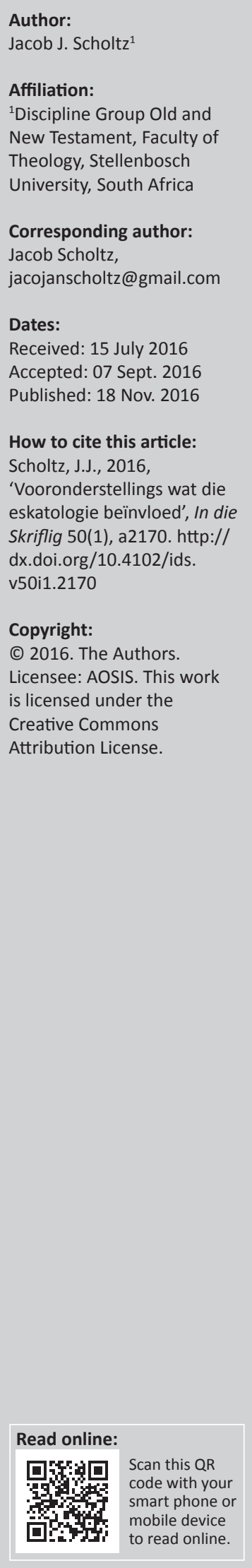

Presuppositions that influence eschatology. If one is to understand where different views about eschatology originate from, then presuppositions of different theological systems must be identified. This article starts such an investigation by focusing on the relation between the two testaments in biblical theology. If the Old Testament is read through the lens of the New Testament, there is a risk that Old Testament truth may be forced into that prior grid. Further analysis follows - for example an investigation into the covenants - leading to a comparison of how presuppositions of covenant theology and dispensationalism impact their views about eschatology. Ways in which the Old Testament is fulfilled in the New Testament - direct, typological, analogical and summary fulfilment - are then considered and discussed. Guidelines for the relation between the two testaments in biblical theology are then proposed and illustrated with an example.

\section{Inleiding}

Om agter die kap van die eskatologiese byl te kom, moet die basis van verskillende teologiese stelsels eers ontleed word alvorens verskillende eskatologiese standpunte geëvalueer kan word. Dit is egter makliker gesê as gedaan, want die kernverskille tussen teologiese stelsels lê nie op die oppervlak nie. Selfs 'n ondersoek na hermeneutiek waarborg nie ooglopende verskille nie (vgl. Ramm 1970:243). Waar kom uiteenlopende eskatologiese standpunte dan vandaan? Dit blyk dat vooronderstellings 'n groot impak op eskatologiese standpunte het. Wijnbeek $(1974: 25,29)$ waarsku byvoorbeeld chiliaste oor 'n 'basiese vooringenomendheid' oor onder andere die verhouding tussen die twee testamente. Du Rand (2013:164-176) dui die risiko aan dat 'n 'voorafingenome denkraamwerk of teorie' in die Skrif ingelees kan word wat eskatologiese standpunte kan beïnvloed. Die doel van hierdie artikel is om vooronderstellings wat die eskatologie beïnvloed, te identifiseer.

Nadat die eie aannames kortliks uitgelig is, fokus die artikel op drie sake. Met betrekking tot die verhouding tussen die twee testamente ondersoek die artikel eerstens twee oorhoofse benaderings waarbinne bybelse teologie beoefen word. Hierdie ondersoek bied 'n vastrapplek om verdere ondersoeke te loods soos byvoorbeeld oor verskillende verbonde. Vooronderstellings se impak op die eskatologie van die verbondsteologie en dispensasionalisme word dan in tabelvorm met mekaar vergelyk. Tweedens gee die artikel aandag aan die verskillende maniere waarop die $\mathrm{Ou}$ Testament in die Nuwe Testament vervul word en die impak hiervan op die eskatologie word aangedui. Derdens stel die artikel riglyne voor wanneer die verhouding tussen die twee testamente in bybelse teologie oorweeg word en illustreer dit aan die hand van 'n voorbeeld.

\section{Eie aannames}

Omdat die goddelike inspirasie van die Skrif in die geskiedenis plaasgevind het en volgens grammatiese reëls neergeskryf is, gaan die grammaties-historiese metode saam met die hermeneutiese beginsel van normale, letterlike interpretasie (sensus literalis). Die beginsel van letterlike interpretasie sluit sowel die letterlike as die figuurlike taalgebruik in. In die geval van letterlike taalgebruik is die betekenis van die teks geredelik verstaanbaar; wanneer figuurlike taal gebruik word, moet die onderliggende letterlike betekenis egter eers in ag geneem word voordat die beeld geïnterpreteer kan word (Tan 1974:142-143). Simbole in die Bybel is emblematies van letterlike realiteite; simbole elimineer nie die teks se letterlike betekenis nie (Geisler 2011:1322, 1345; vgl. ook Ramm 1970:243). Die beginsel van letterlike interpretasie 'sees a distinction between symbols and symbolic or figurative language. The latter receives full recognition, but the former may have a meaning that is quite literal and historical' (Thomas 1992:36). Die hermeneutiese beginsel van normale, letterlike interpretasie is nie 'n plat, een-dimensionele letterlikheid nie; dit sluit figuurlike en simboliese taalgebruik in en neem literêre strukture en genres in ag.

Betekenis moet in die Skrifteks gevind word en nie onder, agter of bo die teks nie (Geisler 2011:79) ook nie vóór die teks nie (in teenstelling met Thiselton 1980:15-16). Onder die inspirasie van die 
Heilige Gees het sommige mense die oorspronklike teks van die Bybel neergeskryf en betekenis is in die teks vasgemaak. God waarsku dat niemand iets by sy Woord mag wegvat of byvoeg nie (vgl. Deut 4:2; Spr 30:6; Op 22:18-19). Die betekenis van' $n$ teks is vas, stabiel en genoegsaam bepaalbaar. 'n Teks se betekenis kan nie verander nie, maar toepassings daarvan kan verander (Hirsch 1967:8). Latere toepassings van die Ou Testament in die Nuwe Testament kan bykomende referente (references plenior) aandui, wat die betekenis in die Nuwe Testament kan laat uitbrei (Kaiser 2008a:155). Desnieteenstaande, omdat die Skrif nie gebreek of ongeldig verklaar kan word nie (Joh 10:35; vgl. Matt 5:17-18), word aangeneem dat ' $\mathrm{n}$ Ou-Testamentiese teks se betekenis nie in die Nuwe Testament verander nie, want anders sou daar sprake wees van 'n kanon binne' $n$ kanon en sou die integriteit van veral God se Ou-Testamentiese openbaring in twyfel getrek kon word (vgl. ook Kaiser 2008b:52-54).

Omdat God die Bybel geïnspireer het, is die Woord ongetwyfeld 'n eenheid wat samehangend en konsekwent is, selfs al is dit nie op een slag ingegee nie, maar net 'n gedeelte op 'n slag, progressief oor 'n tydperk (vgl. Geisler 2011:584). Bybelse teologie verwys óf na die teologie wat in die Bybel tot uitdrukking kom, óf na 'n sisteem van teologie wat in ooreenstemming met die Bybel is of wil wees (Bright 1967:112). In hierdie artikel word bybelse teologie gedefinieer as 'that branch of theological science which deals systematically with the historically conditioned progress of the self-revelation of God as deposited in the Bible' (Ryrie 1959:12). ${ }^{1}$ Terwyl bybelse teologie die Bybel as bron gebruik om Skrifwaarhede te sistematiseer, is sistematiese teologie se studieveld wyer, want dit dek ook algemene openbaring, sluit geskiedkundige tradisies in en maak ook van ander bronne gebruik (Stallard 1997:16). Wat die verhouding tussen bybelse en sistematiese teologie betref, word aanvaar dat bybelse teologie een van die belangrikste en primêre boublokke van sistematiese teologie is: 'Logically and chronologically Biblical Theology should take precedence over Systematic Theology, for the order of study ought to be introduction, exegesis, historical backgrounds, Biblical Theology, and finally Systematic Theology' (Ryrie 1959:16). ${ }^{2}$

\section{Volgorde en metode vir bybelse teologie}

Heyns (1963:74) sê dat 'n grondprobleem met chiliasme is nie soseer eksegese as sodanig nie, maar eerder die 'ongeregverdige kombinasie van Skrifwaarhede', in die 'wyse waarop eksegetiese resultate met mekaar verbind word'. Die verhouding tussen die twee testamente word vervolgens ondersoek, want dit sal uiteindelik sommige vooronderstellings wat die eskatologie beïnvloed, identifiseer.

1. Hasel (1982) skryf: "A Biblical theology has the task of providing summary interpretations of the final form of the individual Biblical documents or groups of writings and of presenting the longitudinal themes, motifs and concepts that emerge from the Biblical materials' (p. 77).

2. Hasel (1984) merk op: 'Biblical theology rejects any directions superimposed from systematic theology in both structure and content. Biblical theology's strufrom emerge from within its own norms. Systematic theology is not made superfluous through biblical theology. Biblical theology is foundational for systematic theology, through biblical theology. Biblical theology is foundational for systematic theology,
if systematic theology is understood to receive its normative authority from if systematic theolod
Scripture' (p. 127).
Hoe moet die verhouding tussen die twee testamente dan eintlik gesien word? Die Nuwe Testament voeg nuwe openbaring tot die kanon by. Soms hef die Nuwe Testament sekere Ou-Testamentiese bepalings op soos byvoorbeeld die voedselwette en die Levitiese offerstelselgebruike (Lev 11; Mark 7:19; Heb 9). Ander kere maak die Nuwe Testament toepassings van die $\mathrm{Ou}$ Testament en partykeer voeg dit referente tot sommige van die Ou-Testamentiese openbaring by (soos wat later bespreek sal word). Dit gaan geensins oor een testament teenoor die ander nie, maar die volgende vrae bly staan: Wat is die vertrekpunt en daaropvolgende stappe wat in die bybelse teologie gebruik behoort te word - veral wat die verhouding tussen die twee testamente betref? Kan die Nuwe Testament die betekenis van die Ou Testament weerspreek, of sodanig herinterpreteer dat dit in wese die oorspronklike bedoeling van die Ou-Testament se skrywers kan kanselleer? Behoort prioriteit aan een testament bó die ander verleen te word?

\section{Prioriteit van die een testament bo die ander een?}

Omdat die Nuwe Testament die sluitsteen van God se openbaring is en die openbaring van die Seun van God die finale, volledige en duidelike openbaring van God is (Heb 1:2), voer Ramm (1970:167) aan dat teologie op die skouers van die Nuwe Testament behoort te rus: 'Although the Old is prior in time the New is prior in method'. Alhoewel hy die twee testamente as een boek beskou wat een verlossingsgeskiedenis bevat, voer Greidanus (1999:51-52) aan dat die Ou Testament nie net in eie konteks geïnterpreteer moet word nie, maar ook in die konteks van die Nuwe Testament: 'The necessity to read the Old Testament from the perspective of the New also follows from the progressive nature of redemptive history'. Prioriteit aan die Nuwe Testament word ook deur Phillips, Janse van Rensburg en Van Rooy (2012:8-9) gegee, maar hulle dring daarop aan dat die Nuwe Testament nie die oorspronklik bedoelde betekenis van die $\mathrm{Ou}$ Testament tot niet mag maak nie. Hierdie waarskuwing word egter nie orals toegepas nie. Waltke (1988:264) sê byvoorbeeld dat die Nuwe Testament die Ou Testament interpreteer en voeg selfs by dat interpretasies van die $\mathrm{Ou}$ Testament nie die Nuwe Testament mag weerspreek nie. Nog 'n voorbeeld is Riddlebarger (2003:37-38) wat die Nuwe Testament as die finale arbiter oor die Ou Testament beskou, veral wat die eskatologie betref, want as Nuwe-Testamentiese skrywers party Ou-Testamentiese profesieë skynbaar vergeestelik en op 'n nie-letterlike wyse behandel, moet ander Ou-Testamentiese profesieë ook sodanig behandel word. Hoe sou die Nuwe Testament dit dan doen? Met verwysing na die hantering van Hosea 11:1 in Matteus 2:15, sê Ladd (1977:20-21) dat die Nuwe Testament die OuTestamentiese profesieë op 'n manier interpreteer wat nie deur die Ou-Testamentiese konteks aan die hand gedoen word nie en daarom glo hy dat die Ou Testament deur die Nuwe Testament herinterpreteer moet word in die lig van die Christus-gebeurtenis. Die Ou Testament moet binne die groter verlossingsverhaal of metanarratief vertolk word 
(Strauss \& De Wet 2014:2). Bogenoemde kan Benadering A genoem word. Dit verleen ongetwyfeld in die konteks van die bybelse teologie prioriteit aan die Nuwe Testament, en dit het ' $n$ effek op die eskatologie.

'n Tweede benadering kan Benadering $B$ genoem word. ${ }^{3}$ Benadering $\mathrm{B}$ beklemtoon, net soos Benadering A, dat die Persoon en werk van Jesus Christus die sentrale fokus van die hele Skrif van Genesis tot Openbaring is. Omdat latere openbaring in die Bybel op die openbaring voortbou wat God reeds voorheen in die Bybel gegee het, hou voorstanders van Benadering $B$ egter vol dat die beginpunt vir die verstaan van die Ou-Testamentiese skrifgedeeltes steeds die toepassing van die beginsel van normale, letterlike interpretasie op sodanige Ou-Testamentiese skrifgedeeltes is. Die Nuwe Testament mag lig op die Ou Testament werp, kommentaar lewer, addisionele toepassings maak of referente byvoeg, maar soos Vlach (2012:24) aantoon, die Nuwe Testament verander nie die oorspronklike bedoeling van die OuTestamentiese skrywers nie. Die superstruktuur van die bybelse teologie weerspieël die 'revelational foundation from which it has been derived' (Stallard 1997:19). Indien Ou-Testamentiese bybelse teologie as inset vir NuweTestamentiese bybelse teologie dien, kan die Ou Testament steeds konsekwent met behulp van die grammaties-historiese metode geïnterpreteer word, en nie herinterpreteer of selfs geminimaliseer word deur wat kommentators dink die Nuwe Testament oor die Ou Testament sê nie (Pettegrew 2007:196). Net so waarsku J.S. Feinberg $(1988: 76,79)$ dat, tensy die Nuwe Testament dit eksplisiet aandui, progressiewe openbaring nie onvoorwaardelike en steeds onvervulde beloftes of profesieë in die Nuwe-Testamentiese era kan kanselleer of ongedaan maak nie. Wat vir direkte profesieë geld, geld ook vir tipes en antitipes. Die beginsel van letterlike interpretasie erken beslis die gebruik van tipe en antitipe, maar dit is ' $n$ kategoriefout om die grammaties-historiese metode op te hef of met 'n nuwe hermeneutiese metode, genaamd 'tipologiese interpretasie', te vervang (Geisler 2011:1332-1333).

Stallard som die twee benaderings tot bybelse teologie op soos uiteengesit is in Tabel 1 ('Twee benaderings in bybelse en sistematiese teologie').

Bogenoemde opsomming is nuttig, want dit identifiseer vooronderstellings wat nie net hermeneutiese praktyke beïnvloed nie, maar ook 'n impak op die eskatologie het. Indien die interpretasie van die Ou Testament ondergeskik aan die Nuwe Testament (Benadering A se stappe 2 en 3) gestel word, is dit duidelik waar die klassieke debat tussen letterlike en allegoriese interpretasies vandaan kom (Stallard 1997:18). Benadering A is egter nie a priori op 'n vergeestelikings- of metaforiese hermeneutiek gebaseer nie, maar dit is eerder die resultaat van die grammaties-historiese hermeneutiek vir die Nuwe Testament waarmee daar dan terugbeweeg word na dit wat Benadering A dink die Ou Testament leer (Saucy 1993:20). Stallard (1997:18) voer aan 3. Hasel (1978:171-203) bespreek verskeie benaderings om die verhouding tussen die twee testamente te verklaar.
TABEL 1: Twee benaderings in bybelse en sistematiese teologie.

\begin{tabular}{|c|c|c|}
\hline Stap & Benadering A & Benadering B \\
\hline Stap 1 & Erken vooronderstellings. & Erken vooronderstellings. \\
\hline Stap 2 & $\begin{array}{l}\text { Formuleer' } n \text { bybelse } \\
\text { teologie van die Nuwe } \\
\text { Testament gebaseer op } \\
\text { 'n letterlike interpretasie } \\
\text { (grammaties-historiese } \\
\text { metode) van die Nuwe } \\
\text { Testament. }\end{array}$ & $\begin{array}{l}\text { Formuleer'n bybelse } \\
\text { teologie van die Ou } \\
\text { Testament gebaseer op } \\
\text { 'n letterlike interpretasie } \\
\text { (grammaties-historiese } \\
\text { metode) van die Ou } \\
\text { Testament. }\end{array}$ \\
\hline Stap 3 & $\begin{array}{l}\text { Formuleer 'n bybelse } \\
\text { teologie van die Ou } \\
\text { Testament gebaseer op } \\
\text { 'n Nuwe-Testamentiese } \\
\text { begrip van die Ou } \\
\text { Testament. }\end{array}$ & $\begin{array}{l}\text { Formuleer' } n \text { bybelse } \\
\text { teologie van die Nuwe } \\
\text { Testament gebaseer op } \\
\text { 'n letterlike interpretasie } \\
\text { (grammaties-historiese } \\
\text { metode) van die Nuwe } \\
\text { Testament met inagneming } \\
\text { van stap } 2 \text { se resultate. }\end{array}$ \\
\hline Stap 4 & $\begin{array}{l}\text { Lewer' } n \text { bybelse teologie } \\
\text { en daarna' } n \text { sistematiese } \\
\text { teologie deur alle insette te } \\
\text { sistematiseer, insluitende } \\
\text { stappe } 2 \text { en } 3 \text {. }\end{array}$ & $\begin{array}{l}\text { Lewer 'n bybelse teologie } \\
\text { en daarna ' } n \text { sistematiese } \\
\text { teologie deur alle insette te } \\
\text { sistematiseer, insluitende } \\
\text { stappe } 2 \text { en } 3 \text {. }\end{array}$ \\
\hline
\end{tabular}

Bron: Stallard, M., 1997, 'Literal interpretation, theological method, and the essence of dispensationalism', The Journal of Ministry \& Theology, Spring, 16, 18

dat 'n mens nie bo jou bronne kan uitstyg nie, en dat Benadering $B$ beter is omdat dit ' $n$ ware Ou-Testamentiese bybelse teologie behoue laat bly (stap 2 van Benadering B). Dit kan dan as basis vir 'n Nuwe-Testamentiese bybelse teologie dien (stap 3) sodat die bybelse teologie in die sistematiese teologie gebruik kan word (stap 4).

Van watter waarde is bogenoemde ontleding egter indien Benadering A deur sowel chiliaste as nie-chiliaste gevolg word, terwyl Benadering B uitsluitlik deur chiliaste gevolg word? Daar moet duidelik verdere siftingsprosesse ingespan word om bykomende vooronderstellings wat die eskatologie beïnvloed, te identifiseer. Watter ander faktore beïnvloed die keuse tussen hierdie benaderings?

\section{Bybelse teologie en die verbonde}

In die meeste gevalle volg ondersteuners van die verbondsteologie Benadering A, ongeag of hulle amillennialiste, postmillennialiste of premillennialiste is (Chung 2009:133-135; Hoekema 1979:195-201). Volgens verbondsteoloë lê die sleutel tot die eenheid van die hele Skrif, en dus van die twee testamente, in die genadeverbond. Die verbonde word as vorms van een en dieselfde genadeverbond beskou (Osterhaven 2001:303; vgl. ook Robertson 1980:27-52). Die fundamentele eenheid van die $\mathrm{Ou}$ en Nuwe Testament is dus in die eenheid van die genadeverbond deur die verskillende bedelings heen te vind. Verbonde soos die Abrahamitiese, Dawidiese of Nuwe Verbond word ondergeskik gestel aan die een verbond van genade wat prioriteit geniet (vgl. Robertson 1980:52-63). Die genadeverbond funksioneer dus as die één super-idee waarmee verbondsteologie sowel sistematiese as bybelse teologie beoefen. Dispensasionaliste soos Saucy (1993:40) volg Benadering B en lê klem op die voorwaardelike Mosaïese verbond wat met die volk Israel gesluit is asook op die onvoorwaardelike verbonde - hetsy dié wat met die mensdom as geheel (die verbond met Noag), of dié wat met die volk Israel en hulle Joodse verteenwoordigers gesluit is (Abrahamitiese, Land-, Dawidiese en Nuwe Verbond). 
Die verbonde wat in die Bybel geopenbaar is, is ongetwyfeld belangrike boustene om sin van God se openbaring te maak. Aanhangers van Benadering B vra egter of die verbonde van verlossing en werke en genade induktief uit die Skrif gehaal kan word en of hierdie verbonde nie eintlik vooronderstel word nie. Ryrie (2007:100) vra: '(1) Is the covenant of grace stated in Scripture? (2) Even if it is, should it be the controlling presupposition of hermeneutics and theology?' Volgens Couch (2000:158) het prominente verbondsteoloë soos Berkhof en Hodge erken dat daar geen skriftuurlike bewyse vir die werk- en genadeverbond in hulle teologiese stelsel bestaan nie. Ryrie (2007) merk op:

What the covenant theologian does to make up for the lack of specific scriptural support for the covenants of works and grace is to project the general idea of covenant in the Bible and the specific covenants (like the covenant with Abraham) into these covenants of works and grace. No one disputes the fact that covenant is a very basic idea in Scripture and that a number of specific covenants are revealed in Scripture. But there remains still the reality that nowhere does Scripture speak of a covenant of works or a covenant of grace as it does speak of a covenant with Abraham or a covenant with David or a new covenant. (p. 221)

Indien die genadeverbond induktief uit die Bybel bewys kan word, kan dit 'n inset in die bybelse teologie volgens Benadering A wees (stappe 1-3). Indien dit nie induktief uit die Bybel bewys kan word nie, is dit 'n vooronderstelde 'teologiese verbond' wat vanuit die sistematiese teologie (stap 4) op die bybelse teologie (stappe 1-3) afgedwing word. Benadering $\mathrm{B}$ gebruik verbonde wat die Bybel eksplisiet noem en beskryf om bybelse (stappe 1-3) en sistematiese (stap 4) teologie te beoefen. Hierdie twee benaderings is soos twee skepe wat in dienag by mekaar verbyseil: Verbondsteoloë identifiseer verskillende bedelings as vorms van die een genadeverbond, terwyl dispensasionaliste 'n wisselwerking tussen die verskillende onvoorwaardelike en voorwaardelike verbonde erken en die verskillende dispensasies identifiseer.

\section{Verdere implikasies vir die eskatologie}

Watter implikasies het bogenoemde sienings oor die verhouding tussen die twee testamente en oor die verbonde vir die eskatologie? Ten einde verdere implikasies te identifiseer (en uiteindelik te tabuleer), kan die antwoorde op die volgende twee vrae 'n goeie wegspringplek bied: Word die volk Israel in hulle land herstel (of sal hulle nog in hulle land herstel word)?; en Sal Israel as 'n nasionaal-etniese eenheid gered word? Op hierdie vrae is daar baie verskillende antwoorde. Sommige amillennialistiese voorstanders beantwoord albei vrae negatief (Hoekema 1979:200-201), maar Du Rand (2013:186-188; vgl. ook Riddlebarger 2003:194) noem dat nie-Christelike Jode tot bekering sal kom voor die einde. Postmillennialiste beantwoord die eerste vraag negatief (Boettner 1977a:100-101) en die tweede vraag meestal positief. Premillennialistiese voorstanders van Benadering A beantwoord die eerste vraag soms positief en soms negatief, maar die tweede vraag meestal positief (Blomberg 2009:69). Voorstanders van Benadering B beantwoord albei vrae positief, maar 'n verdere onderskeid word met die volgende vraag getref: Regeer Jesus Christus sedert sy eerste koms reeds op die troon van Dawid? Progressiewe dispensasionaliste antwoord positief hierop (Saucy 1993:76), maar tradisionele dispensasionaliste ontken dit (Malan 2014:240).

Wat Israel en die Kerk betref, beskou die meeste voorstanders van Benadering A die Kerk as 'n nuwe, ware of geestelike Israel (vgl. Du Rand 2013:26, 45, 62; Phillips et al. 2012:9), terwyl voorstanders van Benadering B tussen Israel en die Kerk onderskei (Malan 2014:26-29; Saucy 1993:187-188, 210).

Hoe word die koninkryk van God sedert Christus se eerste koms verstaan? Verbondsteoloë onderskryf die 'alreedsmaar-nog-nie'-beskouing van die koninkryk van God. Vir amillennialiste en postmillennialiste verwys die 'nog-nie' na die ewige bestel (Boettner 1977b:120; Du Rand 2013:31-32), maar vir premillennialiste verwys dit na die millennium wat daarna met die ewige bestel sal saamsmelt (Ladd 1977:17). Vir postmillennialiste sluit die 'alreeds'-gedeelte 'n goue eeu van geestelike voorspoed in (Boettner 1977b: 117-118) - 'n beskouing wat amillennialiste en chiliaste nie onderskryf nie. Dit wil voorkom asof slegs chiliaste leer en sommige leer dit met meer oortuiging as ander (vgl. Blomberg 2009:66-86) - dat daar'n verdrukkingstydperk vóór Christus se tweede koms is. Voorstanders van Benadering B - almal chiliaste - kan onderverdeel word in progressiewe dispensasionaliste wat ook die 'alreeds-maarnog-nie'-beskouing huldig (Saucy 1993:110) en tradisionele dispensasionaliste wat 'n 'nee, nog-nie'-benadering volg.

In die voorafgaande is verskillende vooronderstellings geïdentifiseer wat die eskatologie beïnvloed. Alhoewel fyner nuanses onderskei kan word, is die oortuiging dat Tabel 2 ('Eskatologiese standpunte binne die verbondsteologie en die dispensasionalisme')'n billike oorsig van vyf eskatologiese standpunte binne die verbondsteologie (Benadering A) en die dispensasionalisme (Benadering B) uitlig. Hierdie tabel fokus slegs op dieverbondsteologieen die dispensasionalisme, maar die prosesse wat in hierdie artikel gevolg word, kan ook op ander teologiese stelsels toegepas word. ${ }^{4}$

Hoe meer 'n teologiese stelsel na die verbondsteologie neig, hoe meer is dit ' $n$ teologiese stelsel van kontinuïteit, hoe meer word prioriteit aan die Nuwe Testament as normatief vir die verstaan van die $\mathrm{Ou}$ Testament gegee en hoe meer word gelowiges te alle tye eintlik as die 'oorblyfsel' en die 'ware Israel van God' beskou. Daarteenoor, hoe meer 'n teologiese stelsel diskontinuiteit toelaat, hoe meer neig dit na dispensasionalisme, hoe meer beklemtoon dit die stabiliteit van die betekenis van Ou-Testamentiese skrifgedeeltes en hoe meer tref dit 'n onderskeid tussen Israel en die Kerk. Nie-dispensasionaliste beskou die geskiedenis as 'n kontinue verlossingsgeskiedenis. Greidanus (1999:194) beskryf verlossingsgeskiedenis byvoorbeeld as skepping-

4. Wanneer die verskillende teologiese stelsels op 'n skaal van kontinuitteitdiskontinuïteit geplaas word sou daar van links af volgens Pettegrew (2007:182), die volgende kon verskyn: Sewendedagadventisme, Teonomie, Verbondsteologie, Nuwe Verbondsteologie, Progressiewe Dispensasionalisme, Tradisionele Dispensasionalisme en Ultra-Dispensasionalisme. 
TABEL 2: Eskatologiese standpunte binne die verbondsteologie en die dispensasionalisme.

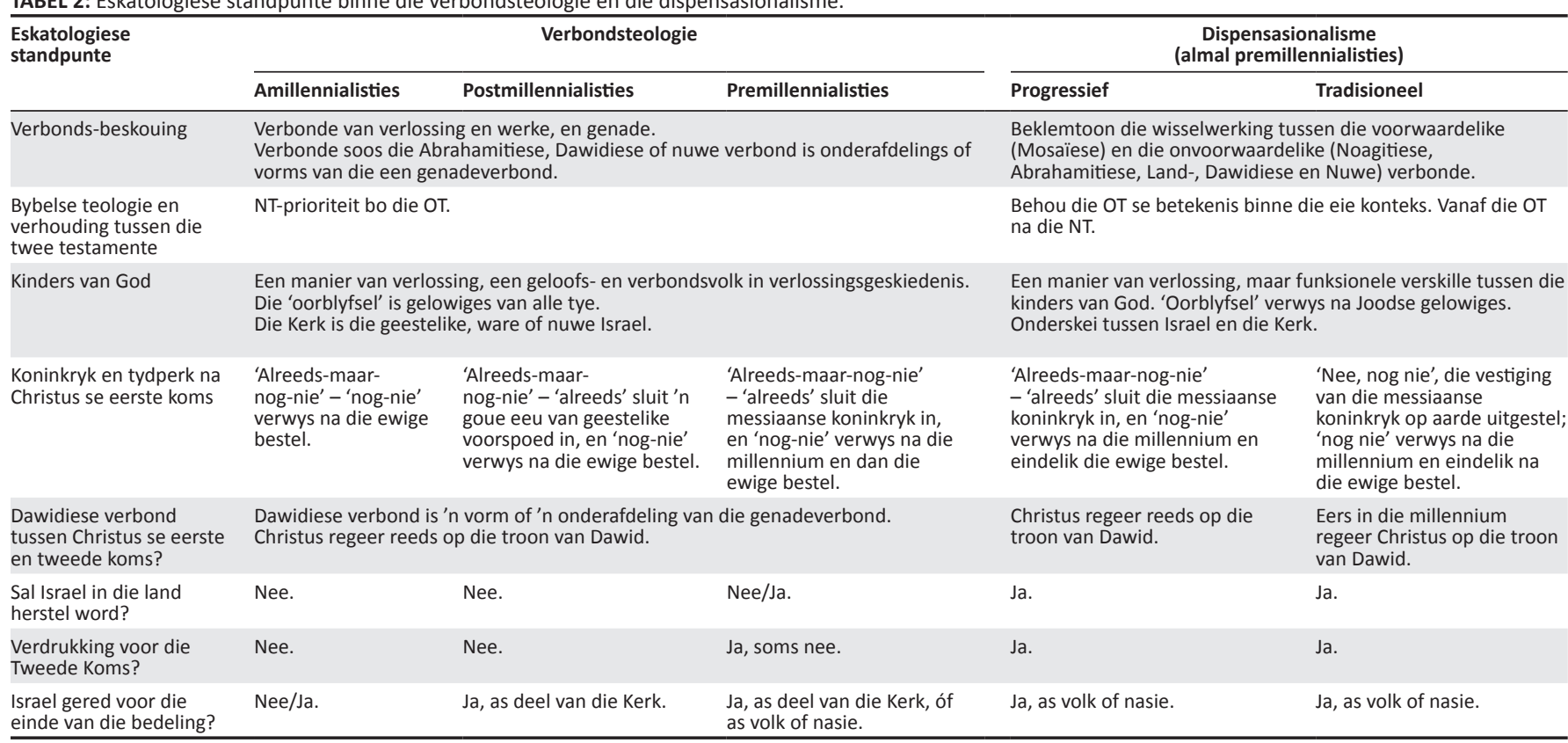

val-verlossing-nuwe skepping en die fokus is op die ontvouing van God se soteriologiese plan om mense te red. 'n Dispensasionele beskouing van die verlossingsgeskiedenis is nader aan die skepping-val-belofte-verlossing-herstel, waar 'herstel' die millennium en dan die nuwe skepping insluit. Die dispensasionele filosofie van die geskiedenis fokus effens meer op die koninkryk van God, waar die koninkryksmotief die verlossing van mense en ook ander aspekte insluit.

Waarom sou iemand die hermeneutiese beginsel van normale, letterlike interpretasie se grammaties-historiese metode, wat letterlike, figuurlike en simboliese taalgebruik kan hanteer, by tye wou ophef? Teoloë soek dikwels regverdiging vir 'n 'spesiale' beginsel van nie-letterlike interpretasie wanneer hulle met die manier werk waarop die Ou Testament in die Nuwe Testament gebruik word. Het die Nuwe-Testamentiese apostels en profete die Ou Testament buite konteks gebruik? Kan hedendaagse eksegete die NuweTestamentiese skrywers se hermeneutiese skuiwe ontsyfer en dit dan navolg? Die wyses waarop Ou-Testamentiese Skrifgedeeltes in die Nuwe Testament vervul word, word vervolgens ondersoek. ${ }^{5}$

\section{Vervulling van die Ou Testament in die Nuwe Testament}

Volgens Cooper (1958:174, 209-215; vgl. ook Rydelnik 2010:95-111) word vier soorte profetiese vervullings van OuTestamentiese skrifgedeeltes in die Nuwe Testament aangetref, naamlik direkte vervulling, tipologiese vervulling, toepassings- of analogiese vervulling en opsommende vervulling. Fruchtenbaum (2016:12-13) sê dat NuweTestamentiese skrywers die Ou Testament aangehaal het op

\footnotetext{
5.Die fokus in hierdie artikel is op die vervulling van die Ou Testament in die Nuwe Testament en nie op byvoorbeeld etiese vervulling (Matt 3.15) of op toespelings van die Ou Testament in die Nuwe Testament nie. Vir meer besonderhede oor laasgenoemde, kyk Beale (2012:55-93), wat 12 maniere identifiseer waarop die Ou laasgenoemde, kyk Beale (2012:55-93), wat 12 maniere identifiseer waarop die Ou
Testament in die Nuwe Testament gebruik word, insluitende byvoorbeeld direkte en Testament in die Nuwe Testament gebruik word, insluitende byvoorbeeld direkte en
tipologiese vervulling asook Paulus se moontlike gebruik van'n allegorie in Galasiërs 4 .
}

dieselfde viervuldige wyse as wat die rabbi's van daardie tyd gedoen het, naamlik pshat (direkte vervulling), remez (tipologiese vervulling), drash (analogiese vervulling) en sod (opsommende vervulling). ${ }^{6} \mathrm{Al}$ het hierdie rabbi's nie-letterlike toepassings gemaak, het hulle nooit die letterlike betekenis van die Skrif of die goddelike inspirasie daarvan ontken nie (ibid:11). Al vier soorte vervulling kom in Matteus 2 voor, en dit word gereeld deur verskeie kommentators gebruik om hulle sienings te staaf. Om hierdie rede word die verskillende soorte vervulling van die $\mathrm{Ou}$ Testament in die Nuwe Testament vervolgens aan die hand van Matteus 2 geilllustreer.

\section{Direkte vervulling}

Matteus 2:5-6 bevat die letterlike vervulling van 'n direkte profesie. Nie net profeteer Miga 5:1 dat die Christus te Betlehem, Efrata, gebore sal word nie, maar 'sy uitgange is uit die voortyd, uit die dae van die ewigheid' (1933/1953-vertaling) - 'n duidelike bewys van die ewigheid en dus die goddelikheid van Christus. Cooper (1958:215-216) identifiseer vier soorte direkte profesieë oor Christus, naamlik profesieë oor sy eerste koms (bv. Deut 18:15-19; Ps 16:8-11; Jes 7:14), profesieë oor sy tweede koms (bv. Ps 2:8-10; Sag 12:10; Matt 23:39), profesieë wat Jesus se eerste en tweede koms inmekaarvleg (bv. Gen 49:10; Jes 9:5-6; Sag 9:9) en profesieë wat die Messias se hele loopbaan uitbeeld (bv. Ps 110; Jes 42:1-4; 61:1-3; 65:1-25).

Die kategorie van letterlike vervulling van 'n direkte profesie (pshat) is relatief eenvoudig, veral as die meeste (of al) die referente van 'n Ou-Testamentiese profesie reeds bekend is. Nie alle direkte profesieë is egter so eenvoudig nie. Sommige direkte Ou-Testamentiese profesieë se referent(e) is nie bekend nie, maar nogtans is die betekenis van daardie Ou-Testamentiese skrifgedeelte genoegsaam bepaalbaar 6.Fruchtenbaum (2016:10-44) gee verskeie rabbynse voorbeelde vir elkeen van hierdie vier maniere van vervulling. 
(Feinberg, P.D. 1988:123). Die letterlike vervulling van direkte profesieë oor byvoorbeeld Christus se tweede koms en oor sy hele loopbaan moet beslis gebeur en uitkom, anders kan dit impliseer - met respek gesê, ter wille van die argument - dat Jesaja of Sagaria byvoorbeeld as vals profete bestempel kan word, wat hulle beslis nie is nie.

\section{Tipologiese vervulling}

Waar Hosea 11:1 'n geskiedkundige gebeurtenis beskryf toe 'n jong volk, Israel, deur God uit Egipte geroep is ('uit Egipte hetEkmyseungeroep'), isMatteus2:15severvullingsaanhaling eweneens 'n bewys dat God die Kindjie wat na die land Egipte gaan, sal bewaar en laat terugkeer ('uit Egipte het Ek my Seun geroep'). Sonder twyfel verwys Hosea 11:1 ook terug na Eksodus 4:22-23, waar die volk Israel beskryf word as God se eersgebore seun wat uit Egipte moet trek. Israel is die nasie-seun van God wat uit Egipte geroep is, terwyl Christus die individuele Seun van God is wat uit Egipte geroep is (Fruchtenbaum 2016:21). Die goddelik-bepaalde tipe- of antitipe-verhouding is duidelik, want Israel sowel as Jesus is 'my seun' wat deur God bewaar en uit Egipte na die land geroep is (vgl. Hagner 2000:36; Nolland 2005:123).

Is Matteus 2:15 se vervulling tipologies, of is dit bloot 'n toepassing of analogie? Omdat Hosea 11:1 'n historiese gebeurtenis beskryf en nie 'n profesie nie, is Ladd (1977:21-23) van mening dat Matteus die Ou Testament in die lig van Christus herinterpreteer om só ' $\mathrm{n}$ 'dieper betekenis' te vind. Rydelnik (2010:101-102) toon egter oortuigend aan dat die volgende goddelik-bepaalde tipe- of antitipe-verhouding in Numeri 23:18-24 en 24:7-9 tot stand gebring word. Wat God vir Israel doen, sal Hy ook vir die toekomstige Koning van Israel doen. Soos God vir Israel uit Egipte geroep het, so sal God die toekomstige Koning van Israel ook uit Egipte roep. Waarom haal Matteus dan vir Hosea aan en nie net Numeri 24:8 nie? Matteus wou nie net Israel of die Koning van Israel se uittog uit Egipte beklemtoon nie, maar ook nasionale Israel en Christus se verhouding as seun en Seun van die Vader (Rydelnik 2010:103-104). Die volgende tabel (Tabel 3: 'Israel as ' $n$ tipe van die toekomstige Koning van Israel') toon duidelik dat 'n tipe- of antitipe-verhouding (remez) in die Pentateug vasgestel is (sien Tabel 3).

Daar is geen grond om te beweer dat Matteus die $\mathrm{Ou}$ Testament ontken, verander, herinterpreteer of buite konteks gebruik het nie. Juis die teendeel is waar.

\section{Toepassings- of analogiese vervulling}

Wanneer Herodes al die seuntjies van twee jaar en jonger in Betlehem en die omstreke laat ombring, gebruik Matteus 2:17 die uitdrukking 'toe is vervul' en haal dan uit Jeremia 31:15 aan. Is Matteus se aanhaling van die $\mathrm{Ou}$ Testament 'kreatief' maar 'ontwykend' soos wat France (2007:88) beweer? Met die Babiloniese inval is Judese jongmanne gevange geneem en by Rama byeengebring voordat hulle deur Nebukadnesar as ballinge na Babel weggevoer is (2007:87). Dit was natuurlik nie Ragel wat
TABEL 3: Israel as ' $n$ tipe van die toekomstige Koning van Israel.

\begin{tabular}{|c|c|}
\hline Israel (Numeri 23:18-24) & Koning van Israel (Numeri 24:7-9) \\
\hline God bring hulle uit Egipte uit. & God bring Hom uit Egipte uit. \\
\hline $\begin{array}{l}\text { God is vir hulle soos die horings van 'n } \\
\text { buffel. }\end{array}$ & $\begin{array}{l}\text { God is vir Hom soos die horings van 'n } \\
\text { buffel. }\end{array}$ \\
\hline Israel is soos 'n leeu. & Die Koning is soos ' $n$ leeu. \\
\hline
\end{tabular}

Bron: Rydelnik, M., 2010, The messianic hope: Is the Hebrew Bible really messianic?, $\mathrm{B} \& \mathrm{H}$ Publishing, Nashville

haar kinders beween het nie (haar liggaam is nie uit die dood opgewek nie), maar Ragel dien as 'n simbool van Joodse moederskap (Fruchtenbaum 2016:24-25). Wat letterlik in die tyd van die Babiloniese ballingskap gebeur het, is dat ' $n$ rouklag en groot gekerm opgegaan het, want Joodse moeders het oor hulle seuns geween wat weggevoer is.

Die vervulling van Jeremia 31:15 waarna Matteus 2:17-18 verwys, is een van toepassing of analogie (drash). 'n Soortgelyke situasie het ontstaan en word deur Matteus gebruik: Joodse moeders ween oor seuntjies wat nie meer daar is nie, en daarom word 'n toepassing of analogie gemaak. Van 'n direkte profesie is hier nie sprake nie, want die referente verskil: Rama teenoor Betlehem, die Babiloniërs teenoor Herodes, jong seuns of mans teenoor seuntjies onder twee jaar. ' $n$ Tipologiese vervulling is dit ook nie, want daar word nie aan die reëls vir tipologiese vervulling (bv. 'n goddelik-bepaalde tipe- of antitipe-verhouding, voorafskaduwing, eskalasie) voldoen nie. Wat Matteus doen, is om iets in een situasie (Jer 31:15) met iets soortgelyks in 'n ander situasie (Matt 2:16-18) in verband te bring, naamlik dat Joodse moeders weer huil oor seun(tjie)s wat nie meer daar is nie. Dit is dus ' $n$ toepassings- of analogiese vervulling.

Toe Joodse moeders tydens die Tweede Wêreldoorlog gesien het hoe hulle seuns op treine na gaskamers toe weggeneem word, het Ragel weer gehuil? Rydelnik (2010:107) sê tereg dat die oorgaan vanaf eksegese tot bybelse beginsels en dan tot hedendaagse toepassings iets is wat byna intuitief gebeur. Wanneer Matteus (en ander Nuwe-Testamentiese skrywers) onder inspirasie sulke toepassings of analogieë uitwys, is daar weereens geen sprake daarvan dat die Ou Testament buite konteks, kreatief of enigmaties gebruik is nie. Juis die teendeel is waar.

In die derde kategorie van vervulling van die Ou Testament in die Nuwe Testament ontstaan die debatte oor midrasj, sensus plenior en references plenior. Die midrasj se doel was nie om Skrifgedeeltes buite hulle literêre kontekste te gebruik of om histories-anachronisties daarmee te werk te gaan nie; inteendeel, die doel van die midrasj vir Joodse rabbi's vóór 70 n.C. was juis om die Skrif in konteks te verstaan en dan relevant en toepaslik vir hulle kontemporêre luisteraars te maak (Beale 2012:3). Die Nuwe Testament het addisionele referente (references plenior) tot die Ou-Testamentiese Skrifgedeeltes bygevoeg om toepassings- of analogiese vervullings in die Nuwe Testament teweeg te bring. Dit verander nog steeds nie die betekenis van die OuTestamentiese teks nie. 


\section{Opsommende vervulling}

Nêrens in die Ou Testament sê enige profeet eksplisiet dat Jesus 'n Nasarener genoem sou word nie. Tog staan in Matteus 2:23 dat die profete dit gesê het. 'n Leidraad na die betekenis hiervan is die verwysing na profete (in die meervoud) 'wat gesê het'. 'n Oorhoofse en algemene tema in die profesie word hier aangeroer, naamlik dat Christus 'n man van smarte sou wees, een wat misverstaan en verwerp sou word (vgl. Jes 53:3; Joh 1:46; France 2007:91-95; Nolland 2005:128). Matteus som dus 'n saak op waaroor al die OuTestamentiese profete saam getuig het. Die vierde soort vervulling van die Ou Testament in die Nuwe Testament is dus opsommende vervulling ( $s o d$ ), want die geïnspireerde teks van die Nuwe Testament getuig opsommenderwys wat die profete gesamentlik oor iets of iemand aangekondig het (Fruchtenbaum 2016:38-40). Hierdie soort NuweTestamentiese vervulling kom minder gereeld voor (bv. Matt 26:56; Hand 3:18-24; Rom 1:2) en dit wil voorkom asof dit uitsluitlik Christologies van aard is.

\section{Bespreking en standpunt}

Matteus 2 se hantering van vier soorte vervulling van die $\mathrm{Ou}$ Testament in die Nuwe Testament kan ontsyfer en deur hedendaagse eksegete van die Bybel nagevolg word. Daar is nie rede om te glo dat die outeurs van die Nuwe Testament die Ou Testament buite konteks of kreatief gebruik het nie, of dat hulle die betekenis van die Ou Testament verander of herinterpreteer nie (Fruchtenbaum 2016:43; Rydelnik 2010:111). Die hermeneutiese beginsel van normale, letterlike interpretasie (grammaties-historiese metode) word nie in die Nuwe Testament opgehef nie; inteendeel, dit word bevestig. Daar is reëls vir die interpretasie van tipes en analogieë, maar dit funksioneer op die hermeneutiese beginsel van die letterlike interpretasie (die grammaties-historiese metode), en daarom kan die allegorisering of vergeesteliking van Skrifgedeeltes op grond van die bestaan van tipes en analogieë nie geregverdig word nie (Feinberg, P.D. 1988:123; Malan 2014:14-16).

Wanneer tipologiese, toepassings- of opsommende vervullings van die $\mathrm{Ou}$ Testament in die Nuwe Testament plaasvind, beteken dit noodwendig dat alle direkte profesieë nou wegval of in bogenoemde tipologiese, toepassings- of opsommende kategorieë van vervulling verander word? Nee, beslis nie. Daar moet ten minste toegegee word dat direkte OuTestamentiese profesieë oor Christus se wederkoms vervul sal word. Maar wat dan van die direkte, onvoorwaardelike en steeds-onvervulde nie-Christologiese verbondsbeloftes of profesieë in die Ou Testament? Sal God dit direk vervul aan die mens(e) vir wie Hy dit belowe het? Wat sodanige profesieë betref, kan onomwonde 'ja' geantwoord word, want God kan nie lieg nie. Hy sal doen wat Hy belowe het aan diegene vir wie Hy dit belowe het, selfs al het Hy só 'n belofte of profesie net een keer gemaak (vgl. Feinberg, J.S. 1988:76-77). Ek stem saam met Turner (1985):

If NT reinterpretation reverses, cancels, or seriously modifies OT promises to Israel, one wonders how to define the word 'progressive'. God's faithfulness to his promises to Israel must also be explained. (p. 282)
Gestel argumentsonthalwe die nasionale Israel is ' $\mathrm{O}$ OuTestamentiese tipe vir die Nuwe-Testamentiese antitipe, naamlik die Kerk. Sou dit impliseer dat onvoorwaardelike en steeds onvervulde Ou-Testamentiese beloftes en profesieë aangaande Israel eksplisiet of implisiet deur die Kerk oorgeneem en getransendeer is? Soms word 'n OuTestamentiese tipe deur die Nuwe-Testamentiese antitipe beëindig. Ou-Testamentiese seremoniële wette en instellings aangaande die Levitiese priesterorde ingevolge die Wet van Moses word byvoorbeeld eksplisiet in die Nuwe Testament tot ' $n$ einde gebring. Is dit egter die geval met alle tipeantitipe-verhoudings? Die onvoorwaardelikheid van sekere beloftes aan Israel kan nie eens implisiet deur die Nuwe Testament van Israel weggeneem word nie. J.S. Feinberg (1988:76) merk tereg op: '[U]nconditional promises are not shadows, nor are the peoples to whom they are given'. Trouens, 'if the NT antitype cancels the meaning of the OT type, the NT must tell us so' (J.S. Feinberg 1988:79).

Dieselfde soort redenasie kan vir analogiese vervullings van die Ou Testament in die Nuwe Testament gebruik word. Indien die Nuwe Testament ' $n$ toepassing maak en 'n nuwe referent tot 'n Ou-Testamentiese belofte of profesie byvoeg, kanselleer dit noodwendig die Ou-Testamentiese referent? Die antwoord is weereens 'nee'. Wanneer Petrus byvoorbeeld op Pinksterdag sê: '[D]it is wat deur die profeet Joël gespreek is' (Hand 2:16), watter soort vervulling van Joël 2:28-32 is hier ter sprake? Dit is nie 'n direkte, tipologiese of opsommende vervulling nie, maar wel ' $n$ toepassings- of analogiese vervulling. Joël 2:28-32 sê dat daar groot kosmologiese veranderings sal plaasvind en dat daar geprofeteer, gedroom en gesigte gesien sal word. Handelinge 2 getuig egter nie van kosmologiese veranderings nie en noem ook die spreek in bekende tale, waaroor Joël 2 niks sê nie. Bowendien is die reëls van tipologie nie nagekom nie en is dit ook nie 'n opsommende vervulling nie. Die analogie of ooreenkoms is dat albei Skrifgedeeltes van 'n uitgieting of uitstorting van die Heilige Gees getuig (vgl. Feinberg, P.D. 1988:125-127). Wanneer die Kerk op die Pinksterfees in Handelinge 2 gebore is en in geestelike seëninge in Christus deel, beteken dit dat die direkte profesie van Joël 2:28-32 nie aan die einde van die bedeling aan Israel vervul sal word nie? Nee, inteendeel, dit sal direk vervul word soos God belowe het.

Wat van 'n opsommende vervulling? Sommige dink dat daar 'n 'realiteitskuif' plaasvind wanneer daar vanaf die $\mathrm{Ou}$ Testament na die Nuwe Testament beweeg word, aangesien profetiese vervulling soms 'bo die grense van die werklikheid uitgaan' (Heyns 1963:27). Het die karakter van die koninkryk dan nie eerder geestelik en hemels as aards of polities geword nie (Waltke 1988:268, 270-271)? En wanneer Christus ons vrede is en Jood asook nie-Jood in Homself tot een nuwe mens skep (Ef 2:11-16), hoe kan Israel dan nog 'n toekoms as 'n nasie hê (Hoekema 1979:199-200)? Blaising (2015:91-93) som die nie-dispensasionele posisie soos volg op: OuTestamentiese beloftes wat aan Israel gemaak is, word in Christus, die Kerk of in die nuwe skepping vervul sodat die realiteitskuif geestelik en Christologies weg van Israel na Christus toe plaasvind; weg van die materiële, die aardse en 
die etniese na 'n hemelse, geestelike en nie-etniese realiteit, oftewel na 'n ander soort Israel - een waar die land, die mense en die nasie getransendeer word. Daar is beslis in Christus 'n geestelike eenheid in die Kerk tussen gelowige Jode en gelowige nie-Jode. Wat regverdiging, heiligmaking of uiteindelike verheerliking betref, is daar hoegenaamd geen bevoordeling van 'n Jood bo 'n nie-Jood, of andersom nie. Die onderliggende vooronderstelling van die niedispensasionele posisie - gebaseer op die idee van één geloofs- en verbondsvolk onder die genadeverbond waar baie verskille deur kontinuiteit opgehef moet word - is dat die geestelike betekenis enige ander soort betekenis uitskakel of kanselleer (vgl. J.S. Feinberg 1988:71-73). Is dit egter waar? Selfs binne plaaslike kerke is daar funksionele verskille. Sommige persone is leiers en ander nie (Heb 13:17); sommige het hierdie gawe en ander het weer daardie gawe (1 Kor 12:28-30). Selfs al is almal een in Christus, beteken dit dat alle funksionele verskille tussen Jood en nie-Jood, slaaf en vryman of man en vrou opgehef is (Gal 3:28)? Nee, dit is nie so nie. Die feit dat Jode en nie-Jode in 'n geestelike sin kinders van Abraham is, maak ook nie van nie-Jode nou skielik Jode of deel van die volk Israel nie (vgl. Saucy 1993:50). Fruchtenbaum $(1989: 76,702)$ vra ’n geldige vraag: As jy glo jy is 'n kind van Abraham, maak dit outomaties van jou ook 'n kind van Jakob (wie se naam na Israel verander is)? Anders gestel: As almal wat aan Christus behoort, kinders van Abraham is, wil dit sê dat al Abraham se kinders aan Christus behoort (vgl. Rom 4:11-12; Gal 3:25-29)? Ook opsommende vervulling kanselleer of verander nie direkte, onvoorwaardelike en steeds onvervulde $\mathrm{Ou}$-Testamentiese beloftes of profesieë nie.

\section{Riglyne vir die verhouding tussen die twee testamente}

$\mathrm{Na}$ aanleiding van die bespreking in hierdie artikel, word die volgende riglyne vir die verhouding tussen die twee testamente voorgestel:

- Wat ook al die verhouding tussen die twee testamente is, die betekenis van Ou-Testamentiese Skrifgedeeltes moet gevind word deur die toepassing van die beginsel van normale, letterlike interpretasie (grammaties-historiese metode). Die betekenis daarvan moet nie primêr in die Nuwe Testament gesoek word nie (Vlach 2012:24). Die Nuwe Testament herinterpreteer, verander of kanselleer nie die betekenis van Ou-Testamentiese Skrifgedeeltes nie.

- As die Ou Testament in die Nuwe Testament vervul word, kan die vervulling as direkte, tipologiese, toepassings- of analogiese, of as opsommende vervulling geklassifiseer word:

- Alle Ou-Testamentiese beloftes of profesieë wat onvoorwaardelik aan sekere persone of sekere groepe mense gegee is en wat steeds in die NuweTestamentiese era onvervul bly, sal direk vervul word vir diegene aan wie dit belowe is. Tipologiese, analogiese of opsommende vervulling kan nie onvoorwaardelike beloftes of profesieë wat aan Israel gemaak is, elimineer nie.
- God se Nuwe-Testamentiese openbaring maak bykomende toepassings en voeg referente by (references plenior), maar dit verander steeds nie die betekenis van die Ou-Testamentiese Skrifgedeelte in sy oorspronklike konteks nie. 'n Nuwe-Testamentiese antitipe verander of kanselleer nie die betekenis van 'n Ou-Testamentiese tipe nie, tensy die Nuwe Testament dit eksplisiet aandui (J.S. Feinberg 1988:79).

- Israel en die Kerk is onderskeibaar; die Kerk is nie die nuwe, ware of geestelike Israel nie.

- $\mathrm{Al}$ is daar sedert Handelinge 2 in Christus ' $n$ geestelike eenheid tussen Joodse en nie-Joodse gelowiges in die Kerk, bly daar verskillende betekenisse vir 'n term soos 'kinders van Abraham', aangesien een betekenis (bv. die geestelike) nie die ander betekenisse (biologies, etnies, nasionaal, ens.) kanselleer nie (Vlach 2012:34-35).

Hoe kan die resultate van hierdie artikel geillustreer word? As voorbeeld word aangedui hoe 'n skuif vanaf die tradisionele dispensasionalisme na 'n amillennialistiese verbondsteologie teweeggebring sou kon word. ${ }^{7}$

Om 'n skuif vanaf tradisionele dispensasionalisme na 'n amillennialistiese verbondsteologie te bewerkstellig, sou die verbond van genade 'n hoër status as die Abrahamitiese-, land-, Dawidiese en Nuwe verbond moet ontvang. Soos die spesiale openbaring progressief met verloop van tyd plaasgevind het, sou die genadeverbond die aansprake van die 'kinders van Jakob/Israel' op die Abrahamitiese-, Land-, Dawidiese en Nuwe verbondsbeloftes kon uitskakel (maar dit is in teenstelling met Rom 9:3-4; Ef 2:11-12). Hierdie proses sou 'n filosofie van die geskiedenis tot gevolg kon hê waar dit hoofsaaklik oor soteriologiese verlossing en die geestelike kinders van Abraham gaan. Dit sou ook 'n bybelse teologie kon meebring wat prioriteit aan die Nuwe Testament bo die $\mathrm{Ou}$ Testament verleen. Hierdie prioriteit sou daartoe kon lei dat die beginsel van normale, letterlike interpretasie (die grammaties-historiese metode) selektief opgehef word. Tipologiese, analogiese of opsommende vervullings van die $\mathrm{Ou}$ Testament in die Nuwe Testament sou dan skynbaar onvoorwaardelike en steeds-onvervulde fisiese, nasionale en etniese Ou-Testamentiese beloftes en profesieë wat aan Israel gemaak is, kon elimineer, kanselleer of herinterpreteer. Die effek hiervan op die lees van die Bybel se metaverhaal sou ingrypend kon wees, byvoorbeeld dat Jesus dan nie tydens sy eerste koms die herstel en oprigting van die DawidiesMessiaanse koninkryk aan daardie geslag in Israel aangebied het nie (vgl. Matt 4-12), maar net van 'n geestelike koninkryk gepraat het. In hierdie geestelike koninkryk sou die Kerk Israel dan permanent vervang het en die Joodse idee van 'n letterlike, politiese, sosiale en nasionale koninkryk waaroor die Koning van die Jode op die troon van Dawid in Jerusalem oor al die nasies op aarde gaan heers, sou dan skynbaar 'n totale vergissing gewees het. Die idee dat Israel in hulle land herstel word, dat daar 'n ongekende en ongeëwenaarde verdrukkingstydperk voorlê, en dat die oorblyfsel van Israel as volk aan die einde van hierdie bedeling gered sal word net 7.Dit is maar een voorbeeld uit heelparty moontlikhede. Tabel 2 en bogenoemde riglyne vir die verhouding tussen die twee testamente word gebruik. 
voordat die Messiaanse koninkryk op aarde opgerig word, word dan verwerp. Indien bogenoemde prosesse plaasvind, word 'n skuif waarskynlik vanaf die tradisionele dispensasionalisme met sy premillennialisme na 'n amillennialistiese verbondsteologie bewerkstellig.

\section{Slot}

Uiteenlopende eskatologiese standpunte is ongetwyfeld die gevolg van verskillende vooronderstellings. In 'n poging om agter die kap van die eskatologiese byl te kom, het hierdie artikel sekere vooronderstellings wat die eskatologie beïnvloed, geïdentifiseer deur die volgende te hanteer: die verhouding tussen die twee testamente in die bybelse teologie, die verbonde, ander relevante aspekte vir die eskatologie en maniere hoe die Ou Testament in die Nuwe Testament vervul word. Eskatologiese standpunte binne die verbondsteologie en die dispensasionalisme is met mekaar in tabelvorm vergelyk en riglyne vir die verhouding tussen die twee testamente is voorgestel en met ' $n$ voorbeeld geillustreer. Selfs al is daar uiteenlopende eskatologiese standpunte, bly die ryke verskeidenheid van beloftes van God in Christus ja en amen (vgl. 2 Kor 1:20).

\section{Erkenning \\ Mededingende belange}

Die outeur verklaar dat hy geen finansiële of persoonlike verbintenis het met enige party wat hom nadelig kon beïnloed het in die skryf van hierdie artikel nie.

\section{Literatuurverwysings}

Beale, G.K., 2012, Handbook on the New Testament use of the Old Testament: Exegesis and interpretation, Baker Academic, Grand Rapids.

Blaising, C.A., 2015, 'The coming kingdom and biblical interpretation', Journal of Messianic Jewish Studies 2015(1), 83-108. (Charles Feinberg Center).

Blomberg, C.L., 2009, 'The posttribulationalism of the New Testament: Leaving "Left behind" behind', in C.L. Blomberg \& W.W. Chung (eds.), A case for historic premillennialism: An alternative to "Left behind" eschatology, pp. 61-87, Baker premillennialism: An altern

Boettner, L., 1977a, 'A postmillennial response', in R.G. Clouse (ed.), The meaning of the millennium: Four views, pp. 95-103, InterVarsity Academic, Downers of the

Boettner, L., 1977b, 'Postmillennialism', in R.G. Clouse (ed.), The meaning of the millennium: Four views, pp. 117-141, InterVarsity Academic, Downers Grove.

Bright, J., 1967, The authority of the Old Testament, SCM, London.

Chung, S.W., 2009, 'Toward the reformed and covenantal theology of premillennialism: A proposal', in C.L. Blomberg \& W.W. Chung (eds.), A case for historic premillennialism: An alternative to "Left behind" eschatology, pp. 133-146, Baker Academic, Grand Rapids.

Cooper, D.L., 1958, Messiah: His historical appearance, Biblical Research Foundation, Los Angeles.

Couch, M., 2000, 'Covenant theology and the doctrine of the church', in M. Couch (ed.), An introduction to Classical Evangelical Hermeneutics: A guide to the history and practice of biblical interpretation, pp. 157-163, Kregel Publications, Grand Rapids.

Du Rand, J., 2013, Die einde, Christelike Uitgewersmaatskappy, Vereeniging.

Feinberg, J.S., 1988, 'Systems of discontinuity', in J.S. Feinberg (ed.), Continuity and discontinuity: Perspectives on the relationship between the Old and New Testaments, pp. 63-88, Crossway, Wheaton.
Feinberg, P.D., 1988, 'Hermeneutics of discontinuity', in J.S. Feinberg (ed.), Continuity and discontinuity: Perspectives on the relationship between the Old and New and discontinuity: Perspectives on the relations
Testaments, pp. 109-130, Crossway, Wheaton.

France, R.T., 2007, The Gospel of Matthew, Eerdmans, Grand Rapids.

Fruchtenbaum, A.G., 1989, Israelology: The missing link in systematic theology, Ariel Ministries, Tustin.

Fruchtenbaum, A.G., 2016, Yeshua: The life of Messiah from a messianic Jewish perspective, vol. 1, Ariel Ministries, San Antonio.

Geisler, N.L., 2011, Systematic theology [in one volume], Bethany House, Minneapolis.

Greidanus, S., 1999, Preaching Christ from the Old Testament: A contemporary hermeneutial method, Eerdmans, Grand Rapids.

Hasel, G.F., 1978, New Testament theology, Eerdmans, Grand Rapids.

Hasel, G.F., 1982, 'Biblical theology: Then, now and tomorrow', Horizons in Biblical Theology, 4(1), 61-93.

Hasel, G.F., 1984, 'The relationship between biblical theology and systematic theology', Trinity Journal, 5(2), 113-127.

Hagner, D.A., 2000, Word biblical commentary: Matthew 1-13, vol. 33A, Thomas Nelson, Nashville.

Heyns, J.A., 1963, Die chiliasme of die duisendjarige ryk, NG Kerk Uitgewers, Kaapstad. Hirsch, E.D., 1967, Validity in interpretation, Yale University Press, New Haven. Hoekema, A.A., 1979, The Bible and the future, The Paternoster Press, Cape Town.

Kaiser, W.C., 2008a, 'Response to Bock', in J. Lunde (ed.), Three views on the New Testament use of the Old Testament, pp. 152-158, Zondervan, Grand Rapids.

Kaiser, W.C., 2008b, 'Single meaning, unified referents: Accurate and authoritative citations of the Old Testament by the New Testament', in J. Lunde (ed.), Three views on the New Testament use of the Old Testament, pp. 45-89, Zondervan, Grand Rapids.

Ladd, G.E., 1977, 'Historic premillennialism', in R.G. Clouse (ed.), The meaning of the millennium: Four views, pp. 17-40, InterVarsity Academic, Downers Grove.

Malan, J.S., 2014, Die laaste dae, FaithEquip, Bellville.

Nolland, J., 2005, The Gospel of Matthew: A commentary on the Greek text, Eerdmans, Grand Rapids. (The New International Greek Testament commentary).

Osterhaven, M.E., 2001, 'Covenant theology', in W.A. Elwell (ed.), Evangelical dictionary of theology 2nd edn., pp. 301-303, Baker Academic, Grand Rapids.

Pettegrew, L.D., 2007, 'The new covenant and new covenant theology', The Master's Seminary Journal 18(1), 181-199.

Phillips, G.Y., Janse van Rensburg, F. \& Van Rooy, H.F., 2012, 'Developing an integrated approach to interpret New Testament use of the Old Testament', In die Skriflig 46(2), Art. \#50, 10 bladsye, http://dx.doi.org/10.4102/ids.v46i2.50

Ramm, B., 1970, Protestant biblical interpretation: A textbook of hermeneutics, Baker Books, Grand Rapids.

Riddlebarger, K., 2003, A case for amillennialism: Understanding the end times, Baker Books, Grand Rapids.

Robertson, O.P., 1980, The Christ of the covenants, Presbyterian \& Reformed Publishing, Phillipsburg.

Rydelnik, M., 2010, The messianic hope: Is the Hebrew Bible really messianic? B\&H Publishing, Nashville. (NAC studies in Bible \& Theology; Series, ed. E.R. Clendenen).

Ryrie, C.C., 1959, Biblical theology of the New Testament, Moody Publishers, Chicago.

Ryrie, C.C., 2007, Dispensationalism, Moody Publishers, Chicago.

Saucy, R.L., 1993, The case for progressive dispensationalism: The interface between dispensational and nondispensational theology, Zondervan, Grand Rapids.

Stallard, M., 1997, 'Literal interpretation, theological method, and the essence of dispensationalism', The Journal of Ministry \& Theology, Spring, 5-36.

Strauss, H.S.W. \& De Wet, F.W., 2014, 'Hermeneutiese uitdagings aan Christosentriese prediking vanuit Ou-Testamentiese narratiewe', In die Skriflig 48(2), Art. \#1717, 11 bladsye. http://dx.doi.org/10.4102/ids.v48i2.1717

Tan, P.L., 1974, The interpretation of prophecy, Assurance Publishers, Rockville.

Thiselton, A.C., 1980, The two horizons, The Paternoster Press, Exeter

Thomas, R.L., 1992, Revelation 1-7: An exegetical commentary, Moody Press, Chicago.

Turner, D.L., 1985, 'The continuity of Scripture and eschatology: Key hermeneutical issues', Grace Theological Journal 6(2), 275-287.

Vlach, M.J., 2012, 'What is dispensationalism?', in J. MacArthur \& R. Mayhue (eds.), Christ's prophetic plans: A futuristic premillennial primer, pp. 19-38, Moody Publishers, Chicago.

Waltke, B.K., 1988, 'Kingdom promises as spiritual', in J.S. Feinberg (ed.), Continuity and discontinuity: Perspectives on the relationship between the Old and New Testaments, pp. 263-287, Crossway, Wheaton.

Wijnbeek, D.H.P., 1974, 'Die chiliasme in die Gereformeerde Kerk en ' $n$ antwoord daarop', In die Skriflig 8(29), 24-34. 